\title{
COMPARISON OF INTRALESIONAL METHOTREXATE WITH TRIAMCINOLONE ACETONIDE IN TREATMENT OF HYPERTROPHIC SCARS
}

\author{
By \\ Saleh Reda Saleh Al-Khateeb, Amr Mohamed Zaki and Emad Mahmoud \\ El-Rewiny \\ Department of Dermatology, Venereology and Andrology, Faculty of Medicine, Al-Azhar \\ University \\ Corresponding Author: Saleh Reda Saleh Al-Khateeb,
}

Phone: +201009913541, E-mail: salehalkhateeb55@gmail.com

\begin{abstract}
Background: Keloid and hypertrophic scars are common dermatological complaints produced by disruption of the normal wound-healing process. Since their earliest description, keloids have beleaguered patients and clinicians alike. These scars can be aesthetically disfiguring, functionally debilitating, and emotionally distressing.

Objective: Our study was carried out on 40 patients complaining of keloids divided into two equal groups A and B from November 2019 to June 2020: Group A: treated by triamcinolone acetinoid (TAC) every three weeks, and Group B treated by methotrexate (MTX) every three weeks for maximum eight sessions, We used multiple intralesional injections until the lesion was blanched. Patients were selected from out-patient clinic of Dermatology, Venereology and Andrology Department of Al-Azhar University Hospitals.
\end{abstract}

Results: The present study showed that the vascularity became normal (score 0 ) in 14 patients (70\%), pink (score 1 ) in 6 patients (30\%) in group A. Twelve patients $(60 \%)$ became with normal vascularity (score 0 ), pink (score 1) in 8 patients (40\%) in group B. Flatting of lesions (score 0) occurred in 14 patients $(70 \%)$, while reduction to $2 \mathrm{~mm}$ (score 1) documented in 6 patients (30\%) in group A, and flattening (score 0) occurred in 10 patients $(50 \%)$, reduction of the lesions to $2 \mathrm{~mm}$ (score 1 ) occurred in 8 patient $(40 \%)$ and 2 patient (10\%) had score (2) height 2-5 mm in group B. Normal pigmentation (score 0) occurred in 16 patients $(80 \%)$, mixed pigmentation (score 2) in 2 patients (10\%) and hyperpigmentation (score 3 ) in 2 patients (10\%) in group A and 6 patients (30\%) showed normal pigmentation (score 0), 2 patients $(10 \%)$ showed mixed pigmentation (score 2), 4 patients (10\%) showed hypopigmentation(score 1) and 8 patients (40\%) showed hyperpigmentation (score 3) in group B. Normal pliability in 16 patients (80\%) (Score 0), 4 patients $(20 \%)$ showed supple pliability (score 1) in group A. Normal pliability (score 0 ) was in 10 patients (50\%), 2 patients (10\%) showed yielding pliability (score 2), and 8 patients (40\%) supple pliability (score 1) in group B. Assessment of the scar was based on Vancouver scar scale.

Conclusion: Triamcinolone acetinoid (TAC) was effective in treatment of hypertrophic scars than methotrexate with statistically significant difference at end of treatment period and follow up.

Keywords: Triamcinolon Acetinoid, Methotrexate, Hypertrophic Scars. 


\section{INTRODUCTION}

Wound healing and Scar formation are complex and progressive process that involves intricate communication and regulation between multiple cellular populations. It has been described as taking place in three main phases: inflammation, proliferation, and remodeling (Trace et al., 2016).

Balance of regulatory pathways of the process of healing is critically required and although patients expect complete tissue regeneration, this is only experienced in fetal tissue and cannot be reproduced in normal human skin. At best, when the wound healing process is regulated correctly, the most appealing scar is thin and hardly visible. However, when the healing pathway does not follow the normal physiologic response, an undesirable scar is produced (Berman et al., 2016).

The inflammatory phase: initiates immediately after skin injury and is completed within the first 48 to 72 hours through release of inflammatory mediators. Proliferation is a broad term for a group of key steps that occur during this phase. Although they begin at various time periods in wound healing, collectively, epithelialization, angiogenesis, granulation tissue formation, and collagen deposition characterize proliferation (Janis and Harrison, 2014). The proliferative phase: can start as early as the first week after injury and can last up to 7 weeks. The hemostatic plug originally created at the time of injury is replaced by granulation tissue. The major components of granulation tissue are macrophages, fibroblasts, proteoglycans, hyaluronic acid, collagen, and elastin (Berman et al., 2016). Remodeling phase: Appropriate wound maturation and remodeling result in a quickly healed and minimally visible scar, whereas prolongation of or deviations from this phase can cause hypertrophic or keloid scars or chronic, no healing wounds (Janis and Harrison, 2014).

From a clinical stand point, keloid scar appears as exaggerated growths of scar tissue in the form of firm, slightly tender, boss elated lumps with a glossy surface with or without telangiectasia. Its epithelium is thinned and occasionally there are focal areas of ulceration (Zhang et al., 2014). Lesions range in consistency from soft and doughy to rubbery and hard, they may be pruritic or painful and can even inhibit normal motion of adjacent tissues. In most cases, hypertrophic scars develop in anatomic locations with high tension, as the shoulders, sternum, knees, neck and ankles. Keloids are more often found on the skin of the anterior chest, earlobes, cheeks, upper arms and shoulders. Less affected locations are the eyelids, cornea, mucous membranes, genitalia, palms and soles, but both can occur at any anatomic location (Nagarur and Raja., 2016).

Initially, the lesion is erythematous, then the color changes into brownish red, then it becomes paler as it ages, it can vary from pink- purple to skin-colored to hypo- or hyper pigmented (Mari et al., 2016).

Treatment modalities for keloids and hypertrophic scars include massage, pressure therapy, radiation, intralesional injections, cryotherapy, silicone based products, surgical excision, lasers, and 
different combinations of two or more treatments (Gauglitz, 2013).

Corticosteroid therapy is one of the preventions and treatments that is used in keloids management, and perhaps the first-line choice of primary health care doctors (Mari et al., 2016). Corticosteroids treat the keloid by decreasing fibroblast proliferation.

Methotrexate as an intra-lesional drug was used in treatment of skin tumors as cutaneous squamous cell carcinoma and keratoacanthoma with satisfactory results. Also, several studies used intra-lesional methotrexate (IL-MTX) in treatment of hypertrophic scars/keloids either alone or as an adjuvant to surgery.For hypertrophic scars and keloids, IL-MTX not only improves thickness and flexibility of scar tissue but also decrease vascularity which results in better functional, aesthetic and psychological impact on the patient (Alamdari et al., 2018).

The aim of this work was to compare the efficacy of intralesional methotrexate with triamcinolone acetonide in treatment of hypertrophic scars.

\section{PATIENTS AND METHODS}

This study included 40 patients with different sized keloid and hypertrophic scars ranged from $2-10 \mathrm{~cm}$ and of less than 2 years duration. The patients, ages ranged from 18 to 50 years, the patient were divided into two equal groups: Group I included 8 males and 12 females, and Group II included 4 males and 16 females. Were selected from out-patient clinic of Dermatology, Venereology and
Andrology Department of Al-Azhar University Hospitals. All patients were subjected to complete medical history, dermatological examination and documented digital photography.

Group A was injected intralesionaly by triamcinolone $(20 \mathrm{mg} / \mathrm{mL})$ using an insulin syringe, 27-gauge needle, and Group B was injected intralesionaly by methotrexate $(25 \mathrm{mg} / \mathrm{mL})$ until the lesion was blanched for a maximum of 8 sessions or until complete flattening of the scar. The session was proceeded by cryotherapy using cryospray technique for 20 seconds at $1 \mathrm{~cm}$ distance from the lesion.

The clinical assessment of the scar based on Vancouver scar scale, the scale scores the scar in four parameter namely pigmentation, vascularity, pliability and height. In addition, the scar length, width and height were also measured using centimeter scale.

\section{Statistical analysis:}

Results of the present study were statistically analyzed using SPSS 25 (IBM, USA). Data were represented as median (interquartile range) or number and percentage. Numerical data were compared using Mann-Whitney $U$ test, while categorical data were compared using Fisher's exact test or Chi-square test as appropriate. $\mathrm{P}$ value $<0.05$ was significant. 


\section{RESULTS}

Regarding demographic data, there was no statistically significant difference between both groups regarding age, sex and duration of lesions. The patients group included $8(40 \%)$ males and 12 $(60 \%)$ females in group A and $4(20 \%)$ males and $16(80 \%)$ females in group B. Their ages ranged from 18 to 50 years (Median=26) in group A, 23 in group B. Duration of the disease was less than 2 years (Table 1).

Table (1): Comparison between studied groups as regard sex, age and duration

\begin{tabular}{|c|c|c|c|c|c|c|}
\hline \multicolumn{2}{|c|}{$\begin{array}{ll}\text { Parameters } & \text { Groups }\end{array}$} & \multicolumn{2}{|c|}{$\begin{array}{c}\text { Group A } \\
(\mathbf{N}=\mathbf{2 0})\end{array}$} & \multicolumn{2}{|c|}{$\begin{array}{c}\text { Group B } \\
(\mathbf{N}=\mathbf{2 0})\end{array}$} & P-value \\
\hline \multirow{2}{*}{ Sex } & Male & 8 & $40 \%$ & 4 & $20 \%$ & \multirow{2}{*}{0.168} \\
\hline & Female & 12 & $60 \%$ & 16 & $80 \%$ & \\
\hline \multirow{2}{*}{ Age (Years) } & Median & \multicolumn{2}{|c|}{26} & \multicolumn{2}{|c|}{23} & \multirow{2}{*}{0.369} \\
\hline & IQR & \multicolumn{2}{|c|}{$21-31$} & \multicolumn{2}{|c|}{$20-30$} & \\
\hline \multirow{2}{*}{$\begin{array}{l}\text { Duration } \\
\text { (months) }\end{array}$} & Median & \multicolumn{2}{|c|}{3} & \multicolumn{2}{|c|}{2.5} & \multirow{2}{*}{0.925} \\
\hline & IQR & \multicolumn{2}{|c|}{$2-3$} & \multicolumn{2}{|c|}{$2-4$} & \\
\hline
\end{tabular}

There was a statistically significant difference ( $\mathrm{p}$-value $<0.05)$ between studied groups as regard pigmentation after treatment, no statistically significant difference ( $\mathrm{p}$-value $>0.05$ ) between studied groups as regard vascularity, pliability and height after treatment and highly statistical significant difference (pvalue $<0.001$ ) between studied groups as regard total score (Table 2).

Table (2): Comparison between studied groups as regard VSS after treatment

\begin{tabular}{|c|c|c|c|c|c|c|}
\hline \multicolumn{2}{|c|}{ VSS Groups } & \multicolumn{2}{|c|}{$\begin{array}{c}\text { Group A } \\
(\mathbf{N}=\mathbf{2 0})\end{array}$} & \multicolumn{2}{|c|}{$\begin{array}{c}\text { Group B } \\
(\mathbf{N}=\mathbf{2 0})\end{array}$} & P-value \\
\hline \multirow{2}{*}{ Vascularity } & 0 & 14 & $70 \%$ & 12 & $60 \%$ & \multirow{2}{*}{0.057} \\
\hline & 1 & 6 & $30 \%$ & 8 & $40 \%$ & \\
\hline \multirow{4}{*}{ Pigmentation } & $\mathbf{0}$ & 16 & $80 \%$ & 6 & $30 \%$ & \multirow{4}{*}{0.007} \\
\hline & $\mathbf{1}$ & 0 & $0 \%$ & 4 & $20 \%$ & \\
\hline & 2 & 2 & $10 \%$ & 2 & $10 \%$ & \\
\hline & 3 & 2 & $10 \%$ & 8 & $40 \%$ & \\
\hline \multirow{3}{*}{ Pliability } & 0 & 16 & $80 \%$ & 10 & $50 \%$ & \multirow{3}{*}{0.095} \\
\hline & 1 & 4 & $20 \%$ & 8 & $40 \%$ & \\
\hline & 2 & 0 & $0 \%$ & 2 & $10 \%$ & \\
\hline \multirow{3}{*}{ Height } & 0 & 14 & $70 \%$ & 10 & $50 \%$ & \multirow{3}{*}{0.229} \\
\hline & 1 & 6 & $30 \%$ & 8 & $40 \%$ & \\
\hline & 2 & 0 & $0 \%$ & 2 & $10 \%$ & \\
\hline \multirow{2}{*}{ Total score } & Median & \multirow{2}{*}{\multicolumn{2}{|c|}{1}} & \multicolumn{2}{|c|}{4.5} & \multirow{2}{*}{$<0.001$} \\
\hline & IQR & & & \multicolumn{2}{|c|}{$2-7$} & \\
\hline
\end{tabular}


In the present study, 30\% had keloid in the arm, $20 \%$ in the shoulder, $20 \%$ in the chest and $10 \%$ in the face, thigh and abdomen in triamcinolone group, while $30 \%$ in the shoulder, $20 \%$ in the arm and abdomen, $10 \%$ in the ear, chest and thigh in methotrexate group. This study showed no statistical significant difference ( $p$ value $>0.05$ ) between studied groups as regard site (Table 3).

Table (3): Comparison between studied groups as regard site

\begin{tabular}{|c|c|c|c|c|c|}
\hline $\begin{array}{ll}\text { Site } & \text { Groups } \\
\end{array}$ & \multicolumn{2}{|c|}{$\begin{array}{c}\text { Group A } \\
(\mathbf{N}=\mathbf{2 0})\end{array}$} & \multicolumn{2}{|c|}{$\begin{array}{c}\text { Group B } \\
(\mathbf{N}=\mathbf{2 0})\end{array}$} & P-value \\
\hline Ear & 4 & $20 \%$ & 2 & $10 \%$ & \multirow{7}{*}{0.109} \\
\hline Shoulder & 0 & $0 \%$ & 6 & $30 \%$ & \\
\hline Abdomen & 2 & $10 \%$ & 4 & $20 \%$ & \\
\hline Arm & 6 & $30 \%$ & 4 & $20 \%$ & \\
\hline Chest & 4 & $20 \%$ & 2 & $10 \%$ & \\
\hline Thigh & 2 & $10 \%$ & 2 & $10 \%$ & \\
\hline Face & 2 & $10 \%$ & 0 & $0 \%$ & \\
\hline
\end{tabular}

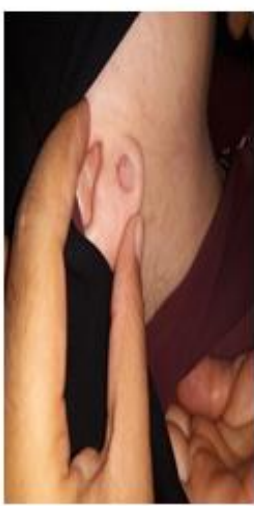

Before

Figure (1): A 30 years old female with keloid before and after treatment showing complete Clearance after 4 sessions of TAC injection.

\section{DISCUSSION}

Numerous methods have been described for the treatment of abnormal scars, but to date, the optimal treatment method has not been established (Rabello et al., 2014). The most common approach is intralesional corticosteroid injection alone or in combination with other treatment modalities. Triamcinolone acetonide (TAC) is the most commonly used intralesional corticosteroid (Wong, 2016). Our study was carried out on forty

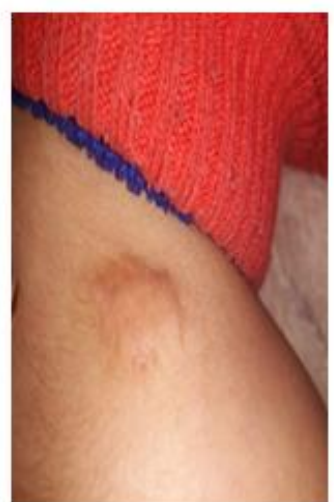

Before

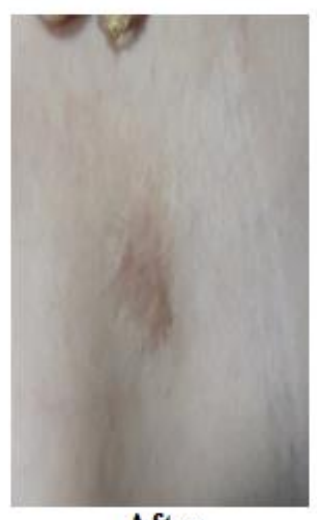

After
Figure (2): An 18 years old female with keloid before and after treatment showing complete clearance after 4 sessions of MTX injection.

patients complaining of hypertrophic scars, twenty patients treated by intralesional injection of TAC every three weeks and twenty patients treated by methotrexate every three weeks, all patients completed the study. Patients were more satisfied regarding improvement of lesions for which they had used triamcinolone acetinoid as compared with methotrexate. Our data showed that triamcinolone acetinoid is more effective than methotrexate in reducing the patient's symptoms and also 
regarding treatment satisfaction in hypertrophic scars while exerting no specific or severe adverse effects. This was in agreement with Uzair et al. (2015) who used intralesional TAC $20 \mathrm{mg}$ in treatment of keloid, a majority $(62.79 \%)$ of patients of keloids showed significant mean reduction in VSS. Similarly, a study done by Garg et al. (2018) who used Intralesional injection TAC $20 \mathrm{mg}$ was administered in the keloid at an interval of 3 weeks, for a total of 6 sessions, over a period of 18 weeks. Vancouver scar scale (VSS) was used to assess the improvement and SPSS 21 for statistical analysis and observed that Intralesional injection triamcinolone acetonide $20 \mathrm{mg} / \mathrm{ml}$ gives very good to excellent improvement in the majority of patients of keloid. Local adverse effects seen were hypopigmentation, atrophy and telangiectasia.

In literature, there are no studies about using intralesional methotrexate alone in treatment of hypertrophic scars. Our study was the first clinical trial to use intralesional methotrexate alone and compare its results to triamcinolone acetinoid. Because of the lack of data, we investigated the beneficial effects of adding metotrexate to patients with hypertrophic scars in a relatively large sample of patients to compare it with TAC. This was in agreement with Sharquie et al. (2014) who used Methotrexate $1 \mathrm{ml}(10 \mathrm{mg}$ with up to a maximum of $2 \mathrm{ml}$ being used per dose) and $0.5 \mathrm{ml}$ triamcinolone acetonide (20mg), $1 \mathrm{ml}$ xylocain $2 \%$ as combination to infiltrate the keloid without removal. Our data showed that triamcinolone acetinoid is more effective than methotrexate in reducing the patient's symptoms, and also regarding treatment satisfaction in hypertrophic scars while exerting no specific or severe adverse effects.

\section{CONCLUSION}

Both triamcinolone acetinoid (TAC) and methotrexate were effective in treatment of hypertrophic scars, but TAC was more effective than methotrexate with statistically significant difference at end of treatment period and follow up.

\section{REFERENCES}

1. Alamdari HA, Davarnia G, Ghadim HH and Sadri A (2018): Intralesional Cryotherapy Versus Intralesional Corticosteroid and 5Fluorouracil in the Treatment of Hypertrophic Scars and Keloids: A Clinical Trial. Crescent Journal of Medical and Biological Sciences, 5(3): 215-221.

2. Berman B, Andrea $M$ and Brian R. (2016): Keloids and Hypertrophic Scars: Pathophysiology, Classification, and Treatment. Dermatol Surg, 43: 3-18.

3. Garg AM, Shah YM, Garg A, Zaidi S, Saxena K, Gupta K and Ramya BG (2018): The efficacy of intralesional triamcinolone acetonide $(20 \mathrm{mg} / \mathrm{ml})$ in the treatment of keloid. International Surgery Journal, 5(3): 868-872.

4. Gauglitz GG (2013): Management of keloids and hypertrophic scars: current and emerging options. Clin Cosmet Investig Dermatol., 6(10):103-117.

5. Janis JE and Harrison B (2014): Wound healing: part I. Basic science. Plast. Reconstr. Surg., 133:199-207.

6. Mari W, Alsabri SG, Tabal N, Younes S, Sherif $A$ and Simman R. (2016): Novel Insights on Understanding of Keloid Scar: Article Review. J. Am. Coll. Clin. Wound Spec., 7: 1-7.

7. Nagarur, K., and Raja, N. R. (2016): A comparative study between intralesional 5fluorouracil combined with triamcinolone acetonide and triamcinolone acetonide alone in the treatment of keloids. International Journal 
of Basic \& Clinical Pharmacology, 5(3): 10901098.

8. Rabello FB, Souza CD and Farina Jr JA (2014): Update on hypertrophic scar treatment. Clinics, 69(8):565-573.

9. Sharquie KE, Noaimi AA,and Al-karhi MR (2014): Debulking of Keloid Combined with Intralesional Injection of Methotrexate and Triamcinolone versus Intralesional Injection of Methotrexate and Triamcinolone. J Clin Dermatol Ther, 1(3):8-21.

10. Trace AP, Enos $\mathrm{Cz}$ W, Mantel $\mathrm{A}$ and Harvey VM (2016): Keloids and Hypertrophic Scars: A Spectrum of Clinical Challenges. Am. J. Clin. Dermatol., 17:201-223.

11. Uzair M, Butt G, Khurshid K. and Pal SS (2015): Comparison of intralesional triamcinolone and intralesional verapamil in the treatment of keloids. Our Dermatology Online, 6(3): 280-293.

12. Wong TS, Li JZH, Chen S, Chan JYW, and Gao W (2016): The efficacy of triamcinolone acetonide in keloid treatment: a systematic review and meta-analysis. Frontiers in Medicine, 3: 71-83.

13. Zhang $Z$, Nie F, Chen $X$, Qin $Z$, Kang C, Chen B, Ma J, Pan B and Ma Y (2014): Upregulated periostin promotes angiogenesis in keloids through activation of the ERK $1 / 2$ and focal adhesion kinase pathways, as well as the upregulated expression of VEGF and angiopoietin1. Mol. Med. Rep., 11:857-864. 


\section{مقارنة بين الحقز الموضعى للميثوتريكسات والتراي أمسينولوز

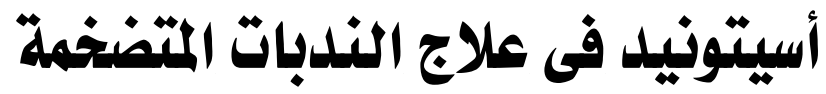

صالح رضا صالح أحمد الخطيب، عمرو محمد زكى، عماد محمود الروينى قسم الأمراض الجلدية والتناسلية وأمراض الذكورة، كلية الطب، جامعة الأزهر

E-mail: salehalkhateeb55@gmail.com

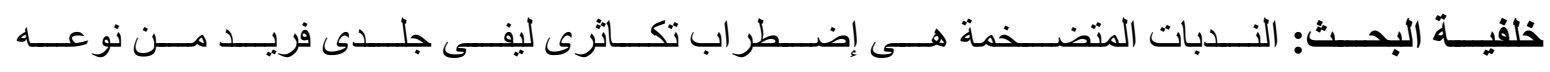

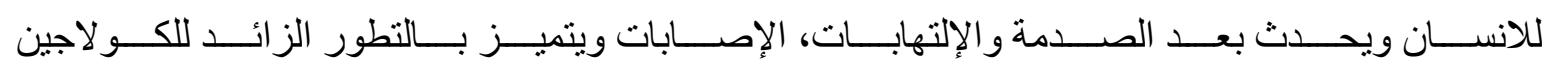

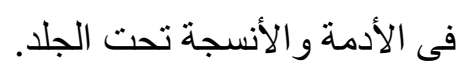

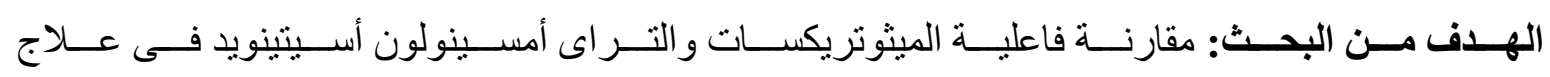
الندبات المتضخمة.

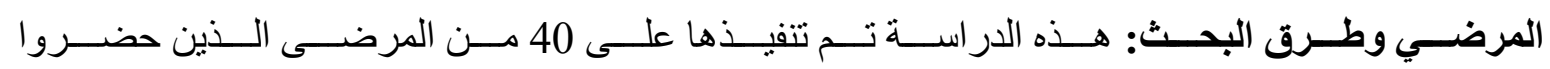

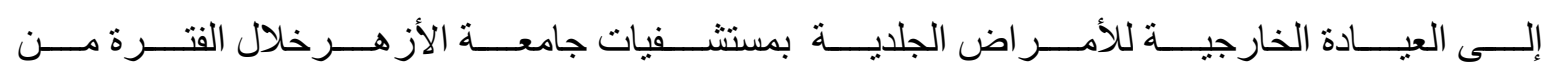

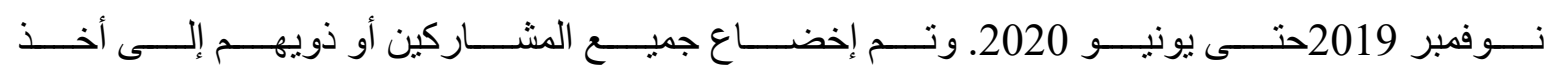

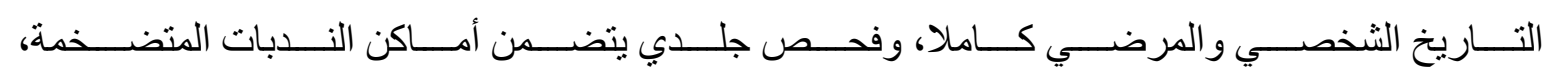
و إلتقاط الصور قبل وبعد العلاج.

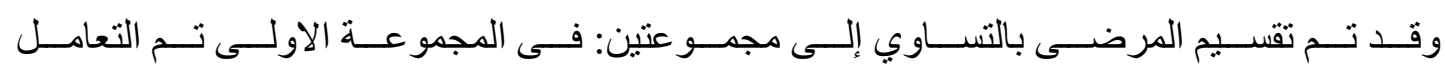

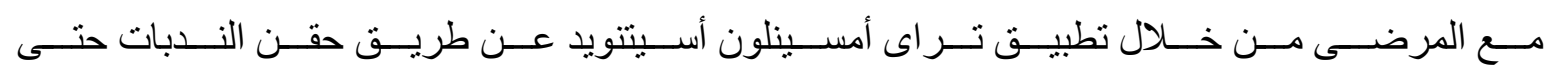

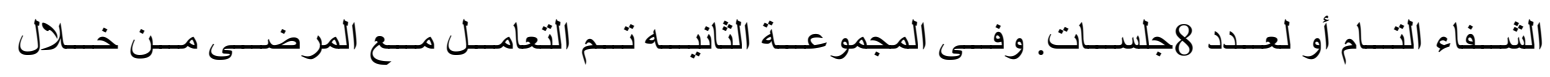

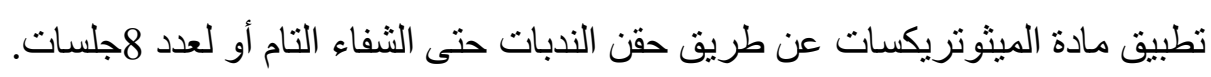

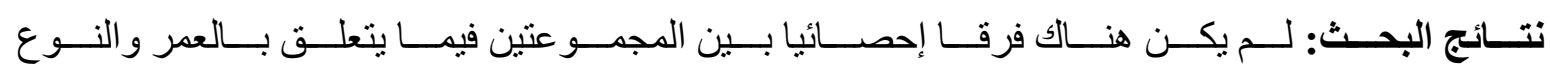

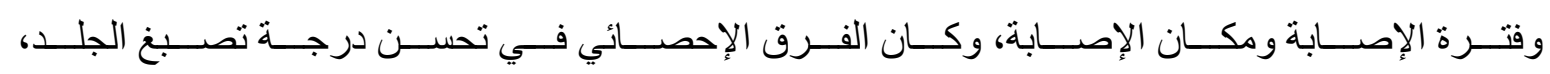
و الاستجابه الكلية للمو اد.

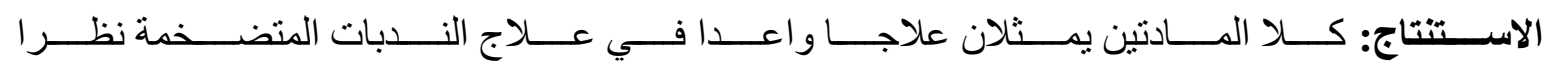
لتوفر هما ورخص ثمنهما مع التوصية باستخدام ماده التراى أمسنولون أسيتنويد. الكلمات الداله: الندبات المتضخمة، الميثوتريكسات،التراى أمسينولون أسيتونويد. 